\title{
S100B-p53 disengagement by pentamidine promotes apoptosis and inhibits cellular migration via aquaporin-4 and metalloproteinase-2 inhibition in $\mathrm{C} 6$ glioma cells
}

\author{
ELENA CAPOCCIA ${ }^{1}$, CARLA CIRILLO $^{2}$, ANNALISA MARCHETTO ${ }^{1}$, SAMANTA TIBERI $^{1}$, \\ YOUSSEF SAWIKR ${ }^{1}$, MARCELLA PESCE ${ }^{3}$, ALESSANDRA D'ALESSANDRO ${ }^{3}$, CATERINA SCUDERI $^{1}$, \\ GIOVANNI SARNELLI ${ }^{3}$, ROSARIO CUOMO ${ }^{3}$, LUCA STEARDO ${ }^{1}$ and GIUSEPPE ESPOSITO ${ }^{1}$
}

\footnotetext{
${ }^{1}$ Department of Physiology and Pharmacology 'Vittorio Erspamer', Sapienza University of Rome, Rome I-00185, Italy;

${ }^{2}$ Laboratory for Enteric Neuroscience, Translational Research Center for Gastrointestinal Disorders, University of Leuven, Leuven 3000, Belgium; ${ }^{3}$ Department of Clinical and Experimental Medicine, Gastroenterology Unit, University of Naples Federico II, Naples I-80131, Italy
}

Received May 16, 2014; Accepted February 10, 2015

DOI: $10.3892 / 01.2015 .3091$

\begin{abstract}
S100 calcium-binding protein B (S100B) is highly expressed in glioma cells and promotes cancer cell survival via inhibition of the p53 protein. In melanoma cells, this S100B-p53 interaction is known to be inhibited by pentamidine isethionate, an antiprotozoal agent. Thus, the aim of the present study was to evaluate the effect of pentamidine on rat C6 glioma cell proliferation, migration and apoptosis in vitro. The change in C6 cell proliferation following treatment with pentamidine was determined by performing a 3-[4,5-dimethylthiazol-2-yl]-2,5 diphenyltetrazolium bromide-formazan assay. Significant dose-dependent decreases in proliferation were observed at pentamidine concentrations of $0.05 \mu \mathrm{M}(58.5 \pm 5 \%$; $\mathrm{P}<0.05), 0.5 \mu \mathrm{M}(40.6 \pm 7 \% ; \mathrm{P}<0.01)$ and $5 \mu \mathrm{M}(13 \pm 4 \% ; \mathrm{P}<0.001)$ compared with the control (100\% viability). Furthermore, treatment with $0.05,0.5$ and $5 \mu \mathrm{M}$ pentamidine was associated with a significant increase in apoptosis versus the untreated cells, as determined by DNA fragmentation assays, immunofluorescence analysis of C6 chromatin using Hoechst staining, and immunoblot analysis of B-cell lymphoma-2 (Bcl-2)-associated $\mathrm{X}$ protein $(100 \%, \mathrm{P}<0.05 ; 453 \%, \mathrm{P}<0.01$; and $1000 \%$, $\mathrm{P}<0.001$, respectively) and $\mathrm{Bcl}-2(-60 \%, \mathrm{P}<0.001 ;-80.13 \%$, $\mathrm{P}<0.001 ;-95 \%, \mathrm{P}<0.001$, respectively). In addition, the
\end{abstract}

Correspondence to: Dr Giuseppe Esposito, Department of Physiology and Pharmacology, 'Vittorio Erspamer', Sapienza University of Rome, 5 Piazzale Aldo Moro, Rome I-00185, Italy

E-mail: giuseppe.esposito@uniroma1.it

Dr Giovanni Sarnelli, Department of Clinical and Experimental Medicine, Gastroenterology Unit, University of Naples Federico II 5 Via Sergio Pansini, Naples I-80131, Italy

E-mail: sarnelli@unina.it

Key words: glioma cells, S100 calcium-binding protein B, p53, pentamidine administration of $0.05,0.5$ and $5 \mu \mathrm{M}$ pentamidine significantly upregulated the protein expression levels of p53 $(681 \pm 87.5 \%$, $\mathrm{P}<0.05 ; 1244 \pm 94.3 \%, \mathrm{P}<0.01$; and $2244 \pm 111 \%, \mathrm{P}<0.001$, respectively), and significantly downregulated the expression levels of matrix metalloproteinase- $2(42 \pm 2.3 \%, \mathrm{P}<0.05 ; 71 \pm 2.5 \%$, $\mathrm{P}<0.01$; and $95.8 \pm 3.3 \%, \mathrm{P}<0.001$, respectively) and aquaporin $4(38 \pm 2.5 \%, \mathrm{P}<0.05 ; 69 \pm 2.6 \%, \mathrm{P}<0.01$; and $88 \pm 3.0 \%$, $\mathrm{P}<0.001$, respectively), compared with the untreated cells. The wound healing assay demonstrated that cell migration was significantly impaired by treatment with $0.05,0.5$ and $5 \mu \mathrm{M}$ pentamidine compared with untreated cells $(88 \pm 4.2 \%$, $\mathrm{P}<0.05 ; 64 \pm 2 \%, \mathrm{P}<0.01$; and $42 \pm 3.1 \%, \mathrm{P}<0.001$, respectively). Although additional in vivo studies are required to clarify the current in vitro data, the present study indicates that pentamidine and S100B-p53 inhibitors may represent a novel approach for the treatment of glioma.

\section{Introduction}

Glioma is one of the most prevalent and aggressive malignant primary tumors of the central nervous system (CNS), accounting for 52 and $20 \%$ of all cases of brain tissue and intracranial tumors, respectively $(1,2)$. It is associated with a poor prognosis, particularly in high grade tumors, such as glioblastoma multiforme (3). The median life expectancy of patients with malignant glioma is $\sim 12$ months, with a 5-year survival rate after diagnosis of $<5 \%(4,5)$. Although systemic metastases are relatively rare, the infiltrative nature of glioma cells, which are able to migrate into the surrounding brain parenchyma, means achieving total surgical resection is unlikely $(6,7)$. Considering that complete curative resection and radiotherapy are not yet attainable, adjuvant chemotherapy is of major importance in the treatment of malignant gliomas, providing the rationale for the implementation of novel targeted therapies. Thus, the development of novel therapeutic approaches to effectively treat gliomas and increase the positive outcome rate is currently a significant topic in the field of oncology. 
S100 calcium-binding protein B (S100B) is a $20 \mathrm{kDa}$, diffusible, $\mathrm{Ca}^{+2} / \mathrm{Zn}^{+2}$-p53 binding protein that has emerged as a critical signaling molecule as it regulates numerous physiopathological functions including, inflammation, apoptosis and cell growth (8). S100B appears to be upregulated in numerous neurodegenerative diseases, including Alzheimer's and Parkinson's disease, and is known to be overexpressed in the majority of malignant gliomas (9-11). Furthermore, the S100B protein has been proposed to significantly contribute to cancer development by inhibiting the function of tumor suppressor protein p53 $(12,13)$, and by stimulating the activity of the mitogenic kinases nuclear dbf2-related (14) and protein kinase B (15). Evidence of S100B/p53 crosstalk, and its impact on cell proliferation and survival, has been the focus of research efforts regarding the development of inhibitors of the S100B-p53 protein-protein interaction. This molecular paradigm represents a novel target for the treatment of the majority of aggressive types of cancer in which S100B protein is highly expressed, such as melanoma (16). For analogous reasons, direct molecular targeting of the S100B protein in glioma appears to be an innovative approach for the development of novel therapeutic interventions against this form of cancer.

Pentamidine isethionate, an agent that exhibits antiprotozoal activity and is approved for the treatment of Pneumocystis cariini pneumonia in the United States, appears to be a promising candidate for the aforementioned S100B-targeting of glioma. In addition to its antiprotozoal activity, pentamidine has been reported to inhibit the S100B-p53 interaction in vitro in melanoma cells (17). However, to the best of our knowledge, no data has yet been determined regarding the possible antiproliferative and antimigratory effects exerted by pentamidine on glioma cells. Therefore, the present study used C6 rat glioma cell cultures to evaluate the in vitro effects of pentamidine on cell proliferation and survival. C6 cells were utilized as a number of studies have revealed that the changes in gene expression observed in the C6 cell line closely resembles those reported in human brain tumors (18-21). Notably, C6 rat glioma cells possess the most important features of human gliomas, exhibiting a mutant p16/cyclin-dependent kinase inhibitor 2a/Ink4a locus (22), high S100B expression levels and no expression of the p53 protein (23). Thus, C6 rat glioma cells are ideal candidates for exploring the activity of novel compounds with anti-glioma activity.

\section{Materials and methods}

Materials. Media, substances and reagents for cell cultures were all purchased from Sigma-Aldrich (St. Louis, MO, USA), unless otherwise stated. Instruments, reagents and materials for western blot analysis were obtained from Bio-Rad Laboratories (Milan, Italy), and pentamidine isethionate was purchased from Tocris Cookson, Inc. (Ballwin, MO, USA). Monoclonal mouse anti-p53 (cat. no. sc-393031, Santa Cruz Biotechnology Inc., Santa Cruz, CA, USA), polyclonal rabbit anti-matrix metalloproteinase-2 (MMP-2; cat. no. ab37150, Abcam, Cambridge, UK), polyclonal mouse anti- $\beta$-actin (cat. no. sc-130656, Santa Cruz Biotechnology Inc.); polyclonal mouse anti-B-cell lymphoma-2 (Bcl-2)-associated X protein (BAX; cat. no. ab18210), monoclonal rabbit anti-Bcl-2 (cat. no. ab87435) and monoclonal rabbit anti-aquaporin 4 (AQP4; cat. no. ab128906) antibodies were obtained from Abcam (Cambridge, UK); and polyclonal rabbit anti-mouse IgG from Dako (Glostrup, Denmark).

Cell culture and pentamidine treatment. C6 rat glioma cells (American Type Culture Collection, LGC Standards, Middlesex, UK) were cultured in Dulbecco's modified Eagle's medium (DMEM) supplemented with 5\% fetal bovine serum (FBS), $2 \mathrm{mM}$ glutamine, $100 \mathrm{U} / \mathrm{ml}$ penicillin, and $100 \mu \mathrm{g} / \mathrm{ml}$ streptomycin in a humidified atmosphere of $5 \% \mathrm{CO}_{2}$ and $95 \%$ air at a temperature of $37^{\circ} \mathrm{C}$. A total of $1 \times 10^{6} \mathrm{cells} /$ well were plated and incubated for $24 \mathrm{~h}$ under the same conditions as those utilised for the initial culture. Upon reaching confluence, the cells were washed three times with phosphate-buffered saline (PBS), detached with trypsin/EDTA, plated in 10-cm diameter petri dish and allowed to adhere for $24 \mathrm{~h}$. Subsequently, DMEM was replaced with fresh medium, and the cells were treated with increasing concentrations of pentamidine isethionate $(0.05,0.5$ and $5 \mu \mathrm{M})$ dissolved in ultrapure and pyrogen-free sterile water at different time points, as described below. The pentamidine concentrations used in the current experiments were selected according to the results of a series of pilot experiments aimed at identifying the lowest effective concentration (data not shown).

Cell proliferation and survival assays. Cell proliferation was evaluated by performing a 3-[4,5-dimethylthiazol-2-yl]-2,5 diphenyltetrazolium bromide (MTT) assay (24). In brief, C6 cells $\left(5 \times 10^{4}\right)$ were plated in 96-well plates and allowed to adhere for $2 \mathrm{~h}$. After $2 \mathrm{~h}$, DMEM was replaced with fresh medium and the cells were treated with increasing concentrations pentamidine $(0.05,0.5$ and $5 \mu \mathrm{M})$. After $48 \mathrm{~h}, 25 \mu \mathrm{l}$ MTT ( $5 \mathrm{mg} / \mathrm{ml}$ MTT in DMEM) was added to the cells and the mixture was incubated for an additional $3 \mathrm{~h}$ at $37^{\circ} \mathrm{C}$. Subsequently, the cells were lysed and the dark blue crystals were solubilized using a $125-\mu \mathrm{l}$ solution containing $50 \% \mathrm{~N}, \mathrm{~N}$-dimethylformamide and $20 \%(\mathrm{w} / \mathrm{v})$ sodium dodecylsulphate $(\mathrm{pH} 4.5)$. The optical density (OD) of each well was determined using a PerkinElmer, Inc. (Waltham, MA, USA) microplate spectrophotometer equipped with a $620-\mathrm{nm}$ filter. Cell viability in response to pentamidine administration was calculated using the following equation: Cell viability $(\%)=\left(\mathrm{OD}_{\text {treated }} / \mathrm{OD}_{\text {control }}\right) \times 100$.

Apoptotic cell staining. A total of $5 \times 10^{5}$ cells were seeded onto glass slides, treated with pentamidine $(0.5-5 \mu \mathrm{M})$ for $2 \mathrm{~h}$, washed twice with PBS and fixed with paraformaldehyde for $30 \mathrm{~min}$ at $4^{\circ} \mathrm{C}$. The $\mathrm{C} 6$ cells were stained with Hoechst 33258 for $5 \mathrm{~min}$ prior to analysis by fluorescent microscopy analysis using a Nikon Eclipse 80 microscope (Nikon Instruments, Inc., Amsterdam, Netherlands), and images were captured at a magnification of $\mathrm{x} 10$ using a high-resolution digital camera (Nikon Digital Sight DS-U1; Nikon Instruments, Inc.). Apoptotic cells were characterized by the specific morphological alterations of condensed nuclei and cell shrinkage and counted using CellProfiler 2.1.0 software (Broad Institute, Cambridge, MA, USA).

DNA fragmentation assay. Following treatment with pentamidine, the adherent and non-adherent C6 cells were harvested, 
A

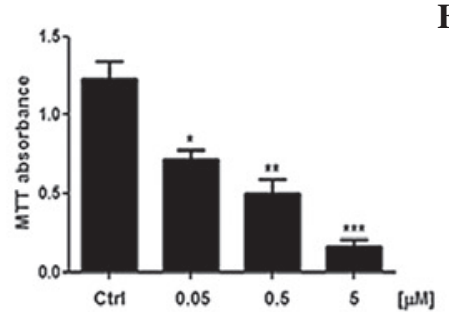

C

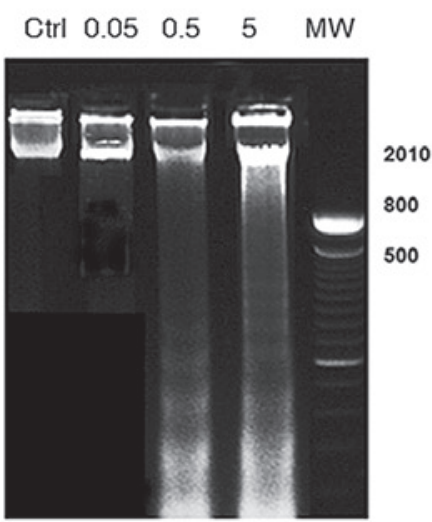

B Ctrl
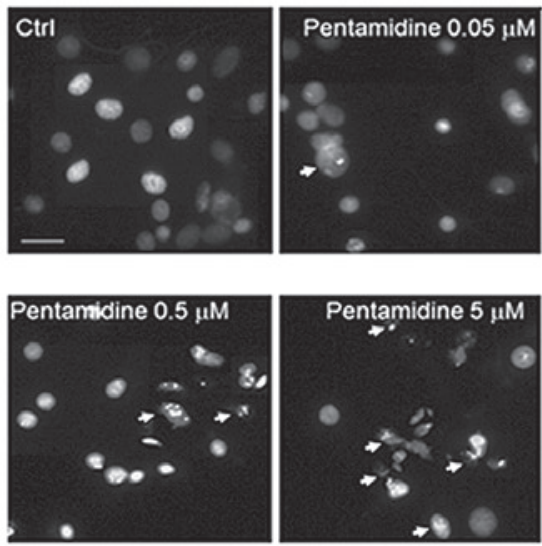

D

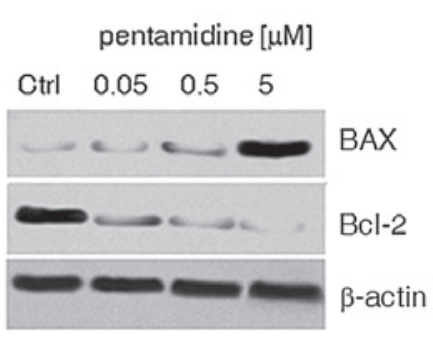

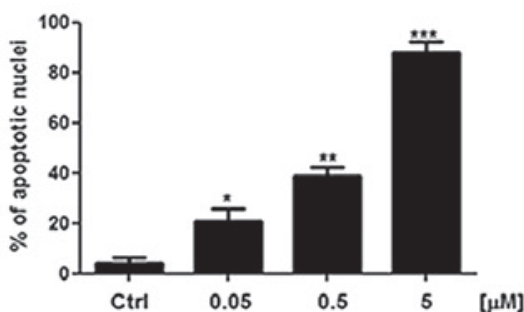

$\mathbf{E}$
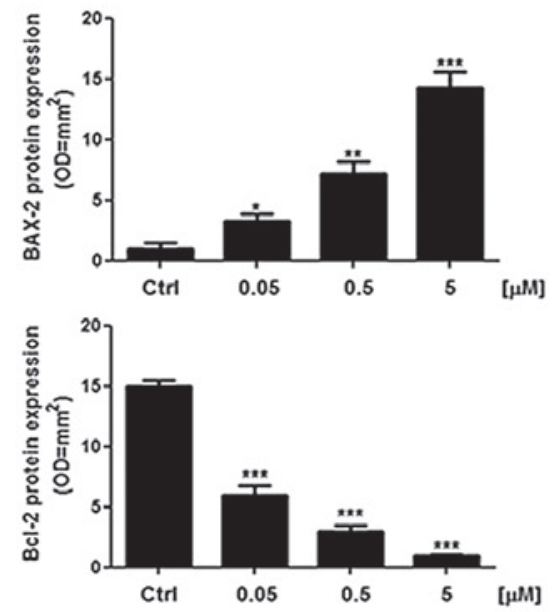

Figure 1. Pentamidine exerts a pro-apoptotic effect on cultured C6 rat glioma cells. (A) An MTT absorbance assay was conducted to determine that pentamidine $(0.05,0.5$ and $5 \mu \mathrm{M})$ induces concentration-dependent inhibition of C6 rat glioma cell proliferation after $48 \mathrm{~h}$. (B) Hoechst staining of C6 rat glioma cell nuclei in the presence or absence of pentamidine $(0.05,0.5$ and $5 \mu \mathrm{M})$ and the relative proportion (\%) of apoptotic nuclei. Pentamidine induces a concentration-dependent increase in the nuclear density of chromatin (arrows) as a marker of apoptosis (scale bar, $20 \mu \mathrm{m}$ ). (C) Agarose gel electrophoresis of cultured C6 rat glioma cell DNA in the presence or absence of pentamidine $(0.05,0.5$ and $5 \mu \mathrm{M})$ for $48 \mathrm{~h}$. The results are representative of $\mathrm{n}=3$ independent experiments. (D) Western blot analysis of pro-apoptotic BAX and anti-apoptotic Bcl-2 proteins. Pentamidine $(0.05,0.5$ and $5 \mu \mathrm{M})$ induces a concentration-dependent increase in BAX expression and a parallel decrease in Bcl-2 expression, demonstrating a clear pro-apoptotic balance in the C6 rat glioma cells. (E) Relative quantification of immunoreactive bands of Bcl-2 and BAX proteins (arbitrary units). Results are expressed as the mean \pm standard error of the mean of $n=5$ experiments performed in triplicate. ${ }^{*} \mathrm{P}<0.05 ;{ }^{* * *} \mathrm{P}<0.01$; and ${ }^{* * * *} \mathrm{P}<0.001$ vs. ctrl cells. MTT, 3-[4,5-dimethylthiazol-2-yl]-2,5 diphenyltetrazolium bromide; ctrl, control; BAX, B-cell lymphoma-2-associated X protein; Bcl-2, B-cell lymphoma-2.

lysed with $400 \mu 1$ sodium chloride EDTA buffer $(75 \mathrm{mM} \mathrm{NaCl}$ and $25 \mathrm{mM}$ EDTA) containing $1 \%$ (w/v) SDS and $2 \mathrm{U} / \mathrm{ml}$ proteinase $\mathrm{K}$, and incubated for $2 \mathrm{~h}$ at $55^{\circ} \mathrm{C}$. Proteins were precipitated by adding $140 \mu 15 \mathrm{M} \mathrm{NaCl}$. After centrifugation at $11,000 \mathrm{x} \mathrm{g}$ for $15 \mathrm{~min}$, DNA in the supernatant was precipitated by addition of $1 \times 10^{3} \mathrm{ml}$ ethanol and centrifugation was performed again (15 min; 11,000 x g). After washing with $70 \%$ ethanol (v/v), the DNA was resuspended in $\mathrm{H}_{2} \mathrm{O}$, separated by agarose gel electrophoresis and stained with ethidium bromide.

Western blot analysis. Protein expression in the C6 cells was evaluated by performing a western blot analysis. Following treatment with pentamidine, cells $\left(1 \times 10^{6}\right)$ were harvested, washed twice with ice-cold PBS and centrifuged at $180 \mathrm{x} \mathrm{g}$ for $10 \mathrm{~min}$ at $4^{\circ} \mathrm{C}$. The cell pellet was resuspended in $100 \mu \mathrm{l}$ ice-cold hypotonic lysis buffer (10 mM HEPES, $1.5 \mathrm{mM}$ $\mathrm{MgCl}_{2}, 10 \mathrm{mM} \mathrm{KCl}, 0.5 \mathrm{mM}$ phenylmethylsulphonylfluoride, $1.5 \mu \mathrm{g} / \mathrm{ml}$ soybean trypsin inhibitor, $7 \mu \mathrm{g} / \mathrm{ml}$ pepstatin $\mathrm{A}$,
$5 \mu \mathrm{g} / \mathrm{ml}$ leupeptin, $0.1 \mathrm{mM}$ benzamidine and $0.5 \mathrm{mM}$ DTT). To lyse the cells, the suspension was rapidly passed through a syringe needle five to six times prior to centrifugation for $15 \mathrm{~min}$ at $13,000 \mathrm{x}$ g to obtain the cytoplasmic fraction. The cytosolic fraction proteins were mixed with non-reducing gel loading buffer (50 mM Tris, 10\% SDS, 10\% glycerol, $2 \mathrm{mg}$ bromophenol $/ \mathrm{ml}$ ) at a 1:1 ratio, boiled for $3 \mathrm{~min}$ and centrifuged at $10,000 \mathrm{x} g$ for $10 \mathrm{~min}$. The protein concentration was determined using a Bradford assay and equivalent quantities $(100 \mu \mathrm{g})$ of each sample were electrophoresed on a $12 \%$ discontinuous polyacrylamide minigel (25). Subsequently, the proteins were transferred onto nitrocellulose membranes that had been saturated by incubation with $10 \%$ non-fat dry milk in $1 \mathrm{X}$ PBS overnight at $4^{\circ} \mathrm{C}$. Each membrane was incubated with mouse anti-BAX (dilution, 1:1000), mouse anti-Bcl-2 (dilution, 1:2000), rabbit anti-MMP-2 (dilution, 1:1000), mouse anti-AQP4 (dilution, 1:5000), mouse anti-p53, (dilution, 1:1000) or mouse anti- $\beta$-actin (dilution, 1:1,000) antibodies for $2 \mathrm{~h}$ at room temperature (RT). 
A

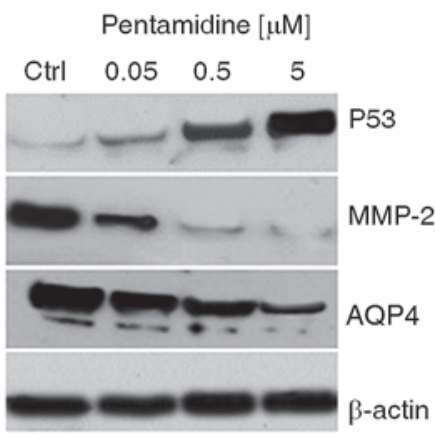

B
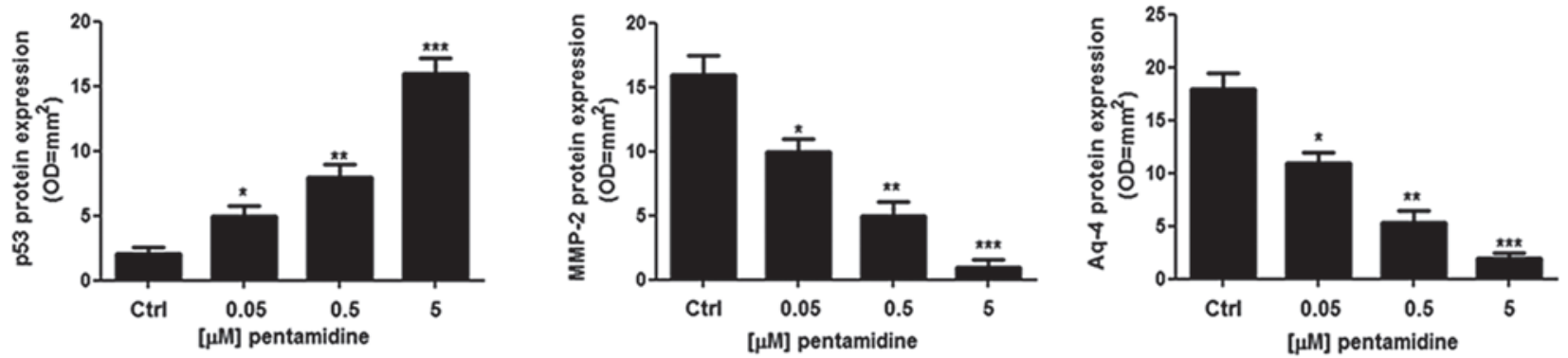

Figure 2. Effect of pentamidine on p53, MMP-2 and AQP4 protein expression levels in C6 rat glioma cells. (A) Western blot analysis demonstrated the effect of pentamidine on p53, MMP-2 and AQP4 protein expression levels in C6 rat glioma cells. (B) Relative quantification of the immunoreactive bands of p53, MMP-2 and AQP4 protein (arbitrary units). Results are expressed as the mean \pm standard error of the mean of $n=5$ experiments performed in triplicate. ${ }^{*} \mathrm{P}<0.05$; ${ }^{* *} \mathrm{P}<0.01$; and ${ }^{* * *} \mathrm{P}<0.001$ vs. ctrl cells. Ctrl. control; MMP-2, matrix metalloprotein-2; AQP4, aquaporin 4; OD, optical density.

The membranes were then incubated with polyclonal rabbit anti-mouse or goat anti-rabbit IgG coupled to horseradish peroxidase (dilution, 1:2000; cat. nos. P0260 and P0448, respectively; Dako, Glostrup, Denmark). Immune complexes were revealed using enhanced chemiluminescence detection reagents (GE Healthcare Life Sciences, Milan, Italy) and by exposing the membranes to Kodak X-Omat film (Eastman Kodak Co., Rochester, NY, USA). Protein bands were then scanned and underwent densitometric analysis using a GS-700 imaging densitometer (Bio-Rad Laboratories).

Wound healing assay. A wound healing assay using the C6 cells was performed as described previously, with a number of modifications (26). Briefly, the C6 cells $\left(5 \times 10^{5}\right.$ cells/well) were plated on a six-well plate and incubated for $24 \mathrm{~h}$ in DMEM supplemented with $5 \%$ fetal bovine serum (FBS), 2 mM glutamine, $100 \mathrm{U} / \mathrm{ml}$ penicillin, and $100 \mu \mathrm{g} / \mathrm{ml}$ streptomycin in a humidified atmosphere of $5 \% \mathrm{CO}_{2}$ and $95 \%$ air at a temperature of $37^{\circ} \mathrm{C}$. The cell layer was scratched using a $200-\mu 1$ sterile pipette tip, then cells were washed with PBS three times and incubated with $0.05,0.5$ and $5 \mu \mathrm{M}$ pentamidine for $48 \mathrm{~h}$. The cells were washed twice with PBS and fixed with $4 \%$ paraformaldehyde for $30 \mathrm{~min}$. In order to facilitate cell counting, the nucleus of the C6 cells was stained with Hoechst 33258 (Invitrogen Life Technologies, Carlsbad, CA, USA) for $5 \mathrm{~min}$ at RT. The cells were subsequently washed three times with PBS and images were captured using a Nikon Eclipse 80 microscope equipped with a high-resolution digital camera (Nikon Digital Sight DS-U1; Nikon Instruments, Inc.). The percentage of migration was calculated by counting the number of cells that had migrated into scratched areas compared with the number of cells that had remained in the peripheral areas.
Statistical analysis. Results are expressed as the mean \pm standard error of the mean of $n$ experiments. Statistical analyses were performed using one-way analysis of variance and multiple comparisons were performed using a Bonferroni post hoc test. $\mathrm{P}<0.05$ was considered to indicate a statistically significant difference.

\section{Results}

Effect of pentamidine on C6 cell proliferation and apoptosis. The administration of pentamidine $(0.05,0.5$ and $5 \mu \mathrm{M})$ to $\mathrm{C} 6$ cells caused a significant concentration-dependent decrease in cell viability $(58.5 \pm 5 \%, \mathrm{P}<0.05 ; 40.6 \pm 7 \%$, $\mathrm{P}<0.01$; and $13 \pm 4 \%, \mathrm{P}<0.001$, respectively) compared with the unstimulated cells (assumed 100\% viability; Fig. 1A). In agreement with this data, a Hoechst assay demonstrated that treatment with pentamidine resulted in a pro-apoptotic effect, with the apoptotic process detected in cell nuclei $48 \mathrm{~h}$ after treatment (Fig. 1B). Furthermore, the pentamidine concentration $(0.05,0.5$ and $5 \mu \mathrm{M})$ was significantly associated with an increase in the proportion of apoptotic nuclei $(21 \pm 5 \%$, $\mathrm{P}<0.05 ; 39 \pm 3.2 \%, \mathrm{P}<0.01$; and $88 \pm 4.1 \%, \mathrm{P}<0.001$, respectively) compared with the untreated C6 cells $(4.5 \pm 1.6 \%)$. In addition, the integrity of the DNA samples extracted from the C6 cells after treatment with pentamidine for $48 \mathrm{~h}$ was analyzed using agarose gel electrophoresis and compared with the DNA samples obtained from the untreated C6 cells. Qualitative analysis of the DNA demonstrated that pentamidine treatment $(0.05,0.5$ and $5 \mu \mathrm{M})$ increased the amount of smearing on the gel in a concentration-dependent manner, while DNA obtained from the untreated cells only travelled a short distance through the gel, indicating its integrity (Fig. 1C). Immunoblot 
A
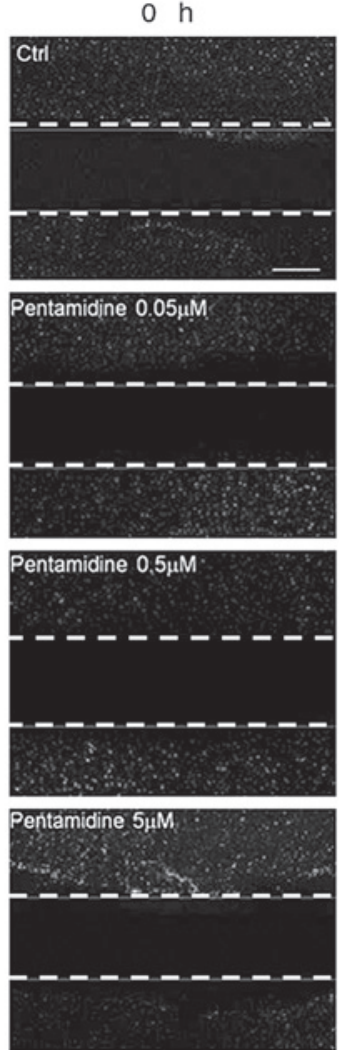

$48 \mathrm{~h}$
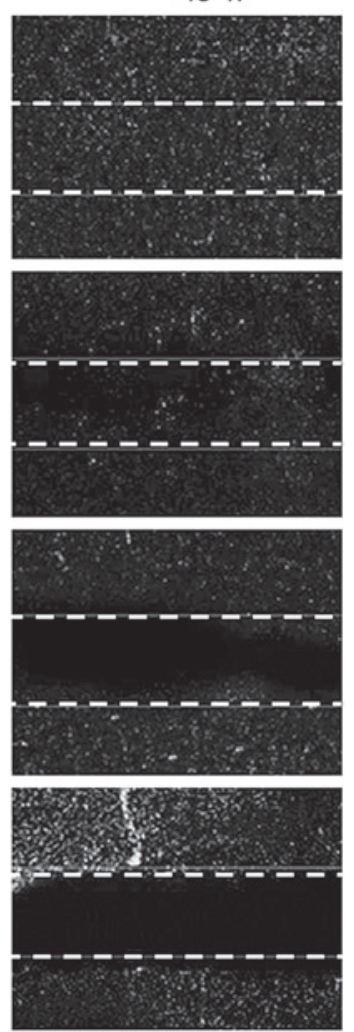

B

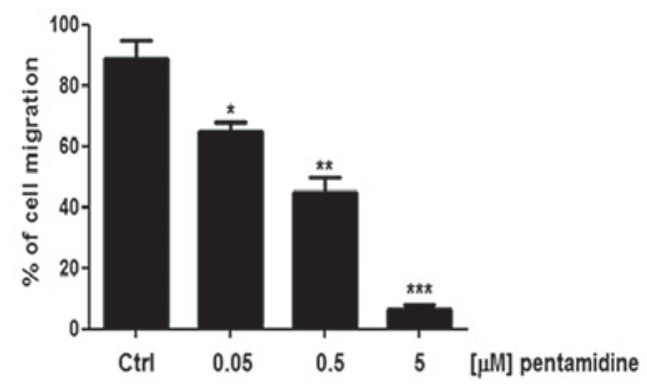

Figure 3. Pentamidine inhibits glioma cell migration in vitro. (A) Wound healing assay demonstrating the effect of pentamidine on cell migration in vitro. Hoechst staining of cell nuclei indicates that pentamidine inhibits the migration of C6 rat glioma cells in a concentration-dependent manner (scale bar, $200 \mu$ m). (B) Quantification of cell migration (\%). Results are expressed as the mean \pm standard error of the mean of $n=4$ experiments performed in triplicate. ${ }^{*} \mathrm{P}<0.05$; ${ }^{* *} \mathrm{P}<0.01 ;$ and ${ }^{* * *} \mathrm{P}<0.001$ vs. ctrl cells. Ctrl, control.

analysis of $\mathrm{BAX}$ and $\mathrm{Bcl}-2$ determined that pentamidine treatment $(0.05,0.5$ and $5 \mu \mathrm{M})$ induced a significant upregulation in BAX protein expression levels in a concentration-dependent manner $(100 \%, \mathrm{P}<0.05 ; 453 \%, \mathrm{P}<0.01$; and $1000 \%, \mathrm{P}<0.001$, respectively) compared with the untreated cells (Fig. 1D and E). This significant increase in the pro-apoptotic effector BAX was paralleled to a significant and concentration-dependent decrease in Bcl-2 protein expression levels following the treatment of C6 cells with $0.05,0.5$ and $5 \mu \mathrm{M}$ pentamidine $(-60 \%$, $\mathrm{P}<0.001 ;-80.13 \%, \mathrm{P}<0.001$; and $-95 \%, \mathrm{P}<0.001$, respectively) compared with untreated cells (Fig. 1D and E).

Effect of pentamidine on p53, MMP-2 and AQP-4 protein expression levels. Compared with the untreated cells, incubation of C6 cells with pentamidine induced a significant and concentration dependent upregulation of p53 protein expression $(681 \pm 87.5 \%, \mathrm{P}<0.05 ; 1244 \pm 94.3 \%, \mathrm{P}<0.01$; and $2244 \pm 111 \%, \mathrm{P}<0.001$, respectively; Fig. $2 \mathrm{~A}$ and B). In line with this, the expression of MMP-2 $(42 \pm 2.3 \%, \mathrm{P}<0.05$; $71 \pm 2.5 \%, \mathrm{P}<0.01$; and $95.8 \pm 3.3 \%, \mathrm{P}<0.001$, respectively) and AQP4 $(38 \pm 2.5 \%, \mathrm{P}<0.05 ; 69 \pm 2.6 \%, \mathrm{P}<0.01$; and $88 \pm 3.0 \%$, $\mathrm{P}<0.001$, respectively) were significantly lower in pentamidine-treated cells compared with untreated cells.

Effect of pentamidine on C6 cell migration in vitro. Malignant gliomas are characterized by aberrant proliferative activity, migration and invasion. The wound healing assay was used to evaluate the putative effect of pentamidine treatment on C6 cell migration. As indicated in Fig. 3A, while untreated C6 cells were able to invade and fully recolonize the scratched area within $48 \mathrm{~h}$, the migration of cells treated with $0.05,0.5$ and $5 \mu \mathrm{M}$ pentamidine was significantly impaired in a concentration-dependent manner $(88 \pm 4.2 \%, \mathrm{P}<0.05$; $64 \pm 2 \%, \mathrm{P}<0.01$; and $42 \pm 3.1 \%, \mathrm{P}<0.001$, respectively), with the distance between the borders of the wound significantly different compared to that measured in the untreated cells. Furthermore, at a concentration of $5 \mu \mathrm{M}$, pentamidine caused an almost complete absence of migration (Fig. 3B).

\section{Discussion}

Despite the aggressive surgical and adjuvant treatments currently used for the management of malignant glioma, few advances have been made in determining the optimal therapeutic approach to this disease (27). However, the results of the present study demonstrate that pentamidine significantly decreases C6 rat glioma cell proliferation, exerting a pro-apoptotic effect and, thus, highlighting pentamidine as a possible therapeutic agent in the treatment of malignant glioma.

Anti-apoptotic Bcl-2 protein, and pro-apoptotic BAX protein are two well-characterized signaling molecules that exhibit opposing functions and expression levels, with their ratio profoundly influencing the rate of cell apoptosis and survival (28). The activity of $\mathrm{Bcl}-2$, a potent inhibitor of 
cell death, has been extensively described in the resistance to numerous anticancer chemotherapeutic agents, as well as in cancer development. By contrast, BAX protein is known to induce apoptosis in various cell lines (29). In concurrence with the antiproliferative activity of pentamidine described in a number of other cell types, including cultured human melanoma cells $(16,17,30,31)$, the results of the present study indicate that pentamidine treatment dose-dependently increases the $\mathrm{BAX} / \mathrm{Bcl}-2$ ratio, demonstrating the pro-apoptotic role of this antiprotozoal agent in cultured glioma cells. The pro-apoptotic effect displayed by pentamidine appears to be directly associated with the inhibition of the S100B-p53 protein-protein interaction, resulting in a marked restoration of wild-type p53 protein function. This effect is considered to be the pivotal mechanism of the anticancer effect of pentamidine $(17,30,31)$. Among the various factors involved in the acquisition of invasive capacities by tumor cells, MMP-2 and AQP4 have emerged as critical markers of glioma cell migration. MMP-2 belongs to a large family of extracellular matrix degrading enzymes, reported to be associated with tumor invasion (32), while AQP4 is a member of the water channel aquaporins (AQPs) that correlate with tumor progression and angiogenesis (33). At least 13 AQPs have been identified in mammals and are expressed by various cell types, including epithelium and endothelium cells (34); among these, AQP4 has a key role in glial cell migration (35). For example, it has been reported that AQP4 is significantly upregulated in glioblastoma compared with low grade gliomas and healthy brain tissue (35). Furthermore, AQP4 knockdown in rat and human cells has been associated with decreased cell migration and invasion, indicating that AQP4 may be involved in glioma malignancy (35). In addition to previous studies describing the antiproliferative effect of pentamidine, the current preliminary data demonstrated that pentamidine treatment caused a profound inhibition of AQP-4 and MMP-2 proteins when compared with untreated C6 cells, resulting in a concentration-dependent inhibition of cell migration rate in vitro. Although the results of the present study are limited by its in vitro approach, the inhibition of the S100B-p53 crosstalk induced by pentamidine may represent a promising pharmacological tool to increase the suppression of glioma cell malignancy. In particular, inhibition of the S100B-p53 interaction appeared to induced a significant pro-apoptotic effect as well as a reduction in the migratory capability of C6 rat glioma cells. As previously stated, surgical resection of glioma is limited due to the high rate of local relapse (35), which may be dependent on MMP-2 and AQP4 expression. Thus, we hypothesize that since pentamidine inhibits the expression of these proteins, it may reduce the risk of local recurrences of glioma.

Agents that are able to induce apoptosis as well as inhibit migration may expand the spectrum of possible pharmacological treatment strategies for cancer, in particular malignant glioma. Thus, pentamidine and other S100B-p53 inhibitors are promising compounds for the treatment of this highly malignant form of cancer. A phase II trial (clinicaltrials.gov; no. NCT00729807) investigating the effect of pentamidine in relapsed or refractory melanoma is currently under evaluation (17). From a translational perspective, pentamidine only exhibits minimal crossing of the blood brain barrier. Therefore, studies have been conducted that aimed to increase the passage of pentamidine into the CNS by modifying its structure prior to its introduction into clinical practice $(36,37)$. However, it has been established that pentamidine is slowly delivered to the CNS via a complex process involving multiple transporters, such as P-glycoprotein and multidrug resistance-associated protein (MRP) transporters (37). In particular, the interaction of $\left[{ }^{3} \mathrm{H}\right]$ pentamidine with P-glycoprotein and MRP has been proposed as a possible strategy to improve the delivery of pentamidine to the CNS (36). Therefore, pentamidine analogues that are able to block the $\mathrm{S} 100 \mathrm{~B}-\mathrm{p} 53$ protein-protein interaction are promising compounds for restoring p53 expression levels in patients with malignant melanoma and other types of cancer that overexpress S100B protein (38).

In conclusion, although the present study is an in vitro preliminary report and requires confirmation in vivo, the results pave the way for the development of novel compounds that may potentially impact on the future treatment strategies of glial cell-originating tumors.

\section{Acknowledgements}

This study was partially supported by Regione Campania (grant. no. L.R. n 5/2001/2008).

\section{References}

1. Mamelak AN and Jacoby DB: Targeted delivery of antitumoral therapy to glioma and other malignancies with synthetic chlorotoxin (TM-601). Expert Opin Drug Deliv 4: 175-186, 2007.

2. Goodenberger ML and Jenkins RB: Genetics of adult glioma. Cancer Genet 205: 613-621, 2012.

3. Crocetti E, Trama A, Stiller C, Caldarella A, Soffietti R, Jaal J, et al; RARECARE Working Group: Epidemiology of glial and non-glial brain tumours in Europe. Eur J Cancer 48: 1532-1542, 2012.

4. Stupp R, Pavlidis N and Jelic S; ESMO Guidelines Task Force: ESMO Minimum Clinical Recommendations for diagnosis, treatment and follow-up of malignant glioma. Ann Oncol 16 (Suppl 1): i64-i65, 2005.

5. Maher EA, Furnari FB, Bachoo RM, Rowitch DH, Louis DN, Cavenee WK and DePinho RA: Malignant glioma: genetics and biology of a grave matter. Genes Dev 15: 1311-1333, 2001.

6. Giese A, Rief MD, Loo MA and Berens ME: Determinants of human astrocytoma migration. Cancer Res 54: 3897-3904, 1994.

7. Louis DN, Pomeroy SL and Cairncross JG: Focus on central nervous system neoplasia. Cancer Cell 1: 125-128, 2002.

8. Donato R, Sorci G, Riuzzi F, et al: S100B's double life: intracellular regulator and extracellular signal. Biochim Biophys Acta 1793: 1008-1022, 2009.

9. Chaves ML, Camozzato AL, Ferreira ED, et al: Serum levels of S100B and NSE proteins in Alzheimer's disease patients. J Neuroinflammation 7: 6, 2010.

10. Sathe K, Maetzler W, Lang JD, et al: S100B is increased in Parkinson's disease and ablation protects against MPTP-induced toxicity through the RAGE and TNF- $\alpha$ pathway. Brain 135: 3336-3347, 2012

11. Weide B, Richter S, Büttner P, et al: Serum S100B, lactate dehydrogenase and brain metastasis are prognostic factors in patients with distant melanoma metastasis and systemic therapy. PLoS One 8: e81624, 2013.

12. Lin J, Yang Q, Yan Z, Markowitz J, Wilder PT, Carrier F and Weber DJ: Inhibiting S100B restores p53 levels in primary malignant melanoma cancer cells. J Biol Chem 279: 34071-34077, 2004.

13. Rustandi RR, Baldisseri DM and Weber DJ: Structure of the negative regulatory domain of $\mathrm{p} 53$ bound to $\mathrm{S} 100 \mathrm{~B}$ (betabeta). Nat Struct Biol 7: 570-574, 2000.

14. Millward TA, Heizmann CW, Schäfer BW and Hemmings BA: Calcium regulation of $\mathrm{Ndr}$ protein kinase mediated by S100 calcium-binding proteins. EMBO J 17: 5913-5922, 1998. 
15. Arcuri C, Bianchi R, Brozzi F and Donato R: S100B increases proliferation in PC12 neuronal cells and reduces their responsiveness to nerve growth factor via Akt activation. J Biol Chem 280: 4402-4414, 2005.

16. Hartman KG, McKnight LE, Liriano MA and Weber DJ: The evolution of S100B inhibitors for the treatment of malignant melanoma. Future Med Chem 5: 97-109, 2013.

17. Smith J, Stewart BJ, Glaysher S, Peregrin K, Knight LA, Weber DJ and Cree IA: The effect of pentamidine on melanoma ex vivo. Anticancer Drugs 21: 181-185, 2010.

18. Sibenaller ZA, Etame AB, Ali MM, Barua M, Braun TA, Casavant TL and Ryken TC: Genetic characterization of commonly used glioma cell lines in the rat animal model system. Neurosurg Focus 19: E1, 2005.

19. Amberger VR, Hensel T, Ogata N and Schwab ME: Spreading and migration of human glioma and rat C6 cells on central nervous system myelin in vitro is correlated with tumor malignancy and involves a metalloproteolytic activity. Cancer Res 58: 149-158, 1998.

20. Gunnersen JM, Spirkoska V, Smith PE, Danks RA and Tan SS Growth and migration markers of rat C6 glioma cells identified by serial analysis of gene expression. Glia 32: 146-154, 2000.

21. Grobben B, DE Deyn PP and Slegers H: Rat C6 glioma as experimental model system for the study of glioblastoma growth and invasion. Cell Tissue Res 310: 257-270, 2002.

22. Schlegel J, Piontek G, Kersting M, Schuermann M, Kappler R, Scherthan $\mathrm{H}$, et al: The p16/Cdkn2a/Ink4a gene is frequently deleted in nitrosourea-induced rat glial tumors. Pathobiology 67 : 202-206, 1999

23. Asai A, Miyagi Y, Hashimoto H, Lee SH, Mishima K, Sugiyama A, et al: Modulation of tumor immunogenicity of rat glioma cells by s-Myc expression: eradication of rat gliomas in vivo. Cell Growth Differ 11: 1153-1158, 1994.

24. Mosmann T: Rapid colorimetric assay for cellular growth and survival: application to proliferation and cytotoxicity assays. J Immunol Methods 65: 55-63, 1983.

25. Bradford MM: A rapid and sensitive method for the quantitation of microgram quantities of protein utilizing the principle of protein-dye binding. Anal Biochem 72: 248-254, 1976.

26. Renault-Mihara F, Beuvon F, Iturrioz X, Canton B, De Bouard S, Léonard N, et al: Phosphoprotein enriched in astrocytes-15 kDa expression inhibits astrocyte migration by a protein kinase $\mathrm{C}$ delta-dependent mechanism. Mol Biol Cell 17: 5141-5152, 2006.

27. Clarke J, Butowski N and Chang S: Recent advances in therapy for glioblastoma. Arch Neurol 67: 279-283, 2010.
28. Rieger L, Weller M, Bornemann A, Schabet M, Dichgans J and Meyermann R: BCL-2 family protein expression in human malignant glioma: a clinical-pathological correlative study. J Neurol Sci 155: 68-75, 1998.

29. Paul-Samojedny M, Kokocińska D, Samojedny A, Mazurek U, Partyka R, Lorenz Z and Wilczok T: Expression of cell survival/death genes: Bcl-2 and Bax at the rate of colon cancer prognosis. Biochim Biophys Acta 1741: 25-29, 2005.

30. Pathak MK, Dhawan D, Lindner DJ, Borden EC, Farver C and Yi T: Pentamidine is an inhibitor of PRL phosphatases with anticancer activity. Mol Cancer Ther 1: 1255-1264, 2002.

31. Zimmer DB, Lapidus RG and Weber DJ: In vivo screening of S100B inhibitors for melanoma therapy. Methods Mol Biol 963: 303-317, 2013.

32. Du R, Petritsch C, Lu K, Liu P, Haller A, Ganss R, et al: Matrix metalloproteinase-2 regulates vascular patterning and growth affecting tumor cell survival and invasion in GBM. Neuro Oncol 10: 254-264, 2008.

33. Ding T, Zhou Y, Sun K, Jiang W, Li W, Liu X, et al: Knockdown a water channel protein, aquaporin-4, induced glioblastoma cell apoptosis. PLoS One 8: e66751, 2013.

34. Verkman AS: Aquaporins in clinical medicine. Annu Rev Med 63: 303-316, 2012.

35. Giese A: Glioma invasion-pattern of dissemination by mechanisms of invasion and surgical intervention, pattern of gene expression and its regulatory control by tumorsuppressor p53 and proto-oncogene ETS-1. Acta Neurochir Suppl 88: $153-162,2003$

36. Sanderson L, Dogruel M, Rodgers J, et al: Pentamidine movement across the murine blood-brain and blood-cerebrospinal fluid barriers: effect of trypanosome infection, combination therapy, P-glycoprotein, and multidrug resistance-associated protein. J Pharmacol Exp Ther 329: 967-977, 2009.

37. Kotthaus J, Kotthaus J, Schade D, et al: New prodrugs of the antiprotozoal drug pentamidine. ChemMedChem 9: 2233-2242, 2011.

38. Raseroka BH and Ormerod WE: The trypanocidal effect of drugs in different parts of the brain. Trans R Soc Trop Med Hyg 80: 634-641, 1986 